\title{
THE DEMOCRATIC QUALITIES OF COURTS: A CRITICAL ANALYSIS OF THREE ARGUMENTS
}

\author{
Richard Bellamy
}

\begin{abstract}
The democratic critique of judicial review by constitutional courts has prompted its defenders to counter that courts have democratic qualities as good as, and in certain respects even stronger than, conventional democratic politics. This article offers a critical analysis of three arguments favouring this approach. The first argues that constitutional courts operate as exemplars of democratic deliberation. In particular, they give expression to the public reasons underlying democracy and ensure democratic practice does not subvert its ideals. The second holds that rights-based litigation offers a form of democratic participation, providing a voice to those who might have been excluded from electoral democracy. The third contends that judges operate in a similar way to elected representatives, who are best conceived as trustees rather than as delegates. All three views are found wanting. Courts do possess certain limited democratic qualities. However, they are not intrinsic features of courts themselves. They arise from their being dependent upon rather than independent from the conventional democratic process.
\end{abstract}

\section{Introduction}

Rights-based judicial review of legislation by constitutional courts has long been criticised as undermining democracy, particularly when it involves a strike down power and a claim to judicial supremacy, a position associated-albeit contentiously-with the US Supreme Court in particular (Hand 1958). However, recent criticisms have given a new twist to this objection. These critiques do not turn on an assumed clash between democratic and constitutional norms. Rather, they rest on the comparative legitimacy and effectiveness of democratic and judicial processes as mechanisms to realise these norms. Within this latest phase of the debate, democracy, on the one hand, and constitutionalism and rights, on the other, are conceived as involving the self-same norms associated with treating autonomous individuals with equal concern and respect. The key claim of the advocates of democracy has not been that constitutionalism is at odds with, or less justified than, democracy but that the democratic process has superior constitutional properties to the judicial process (Bellamy 2007; Tushnet 1999; Waldron 1999). Democracy, understood as a procedure involving regular elections for competing parties, universal suffrage based on one person one vote, and majority rule, is held to provide a mechanism whereby all citizens can see they are treated as equals by virtue of having an equal say in making the collective decisions and rules that shape their common institutions and social interactions, albeit indirectly through their electorally authorised and accountable representatives in the legislature. As such, this system meets the constitutional norms of fairness and impartiality by offering an instrument for ensuring

Representation, 2013

Routledge Taylor \& Francis Group

Vol. 49, No. 3, 333-346, http://dx.doi.org/10.1080/00344893.2013.830485

(C) 2013 The Author(s). Published by Taylor \& Francis.

This is an Open Access article distributed under the terms of the Creative Commons Attribution License (http://creativecommons.org/licenses/by/3.0), which permits unrestricted use, distribution, and reproduction in any medium, provided the original work is properly cited. The moral rights of the named author(s) have been asserted. 
public institutions and arrangements are committed to the equal advancement of the interests of those subject to them. It does so by treating the views individuals have about their own and their society's interests with equal concern and respect and constraining the pursuit of collective policies by the need for governments and the administration to take those views into account. Democratic constitutionalists contend that courts cannot achieve this task as legitimately or effectively because the legal process lacks those features of the democratic process that allow citizens to define and protect their rights on an equal basis. Consequently, courts cannot show their judgments about the rights and rules governing our public lives avoid bias and respect the reasonable disagreements we have about them.

This objection challenges head on a hitherto standard defence of the role of courts that has located their legitimacy and efficacy precisely in their not operating in a democratic manner (Bickel 1986: 24-6). According to this latter line of argument, judicial review is justified as a counter-weight to potentially myopic, prejudiced, careless and occasionally tyrannous majorities and the democratically elected politicians who feel obliged to respond to their demands. Courts are said to avoid such problems through being isolated from the electoral process and independent from government interference. Their reasoning is guided by legal norms and standards of natural justice inculcated by the professional training judges receive, and the expectations and conventions of legal and judicial practice and modes of argument. As a result of this independence, it is claimed that courts take decisions that are less emotive and precipitate than those of democratically accountable legislators and executives, are more likely to respect the rights and interests of overlooked or unpopular minorities, and to accord due weight to long-term advantages and considerations of justice over shortterm gains, administrative convenience and collective utility. However, the democratic critique responds that this model of judicial decision-making involves biases of its own. Given the complexity and plurality of modern societies and the diversity of interests, ideals and experiences of those that live in them, even with the best will in the world the judgments of all individuals will inevitably be partial and limited by their backgrounds and knowledge (Christiano 2008: 88-95). Therefore, insulating the judicial system from democratic pressures runs the risk of rendering courts cognitively biased towards the assumptions and attitudes of those best placed to get their voices heard by entering the legal profession or making use of the courts (Hirschl 2004; Guarini, this issue). To overcome these worries, courts themselves will need to possess certain democratic qualities that can ensure their commitment to the equal advancement of the interests of all persons subject to their authority by demonstrating that they will be treated impartially and in a publicly equal way. For example, it will be important to show that the constitution provides a people's rather than a lawyer's charter and does not unjustifiably favour certain groups within the community at the expense of others; that access to justice is not biased or inequitable; and that the judiciary and lawyers do not form a class apart, out of touch with the circumstances and values of the broader society, and that their recruitment is open and meets equal opportunities criteria.

This article explores three arguments that seek respectively to address each of these points by proposing that courts uphold democratic values, provide a forum for popular participation, and represent isolated minorities and the public interest (e.g., Dworkin 1996, who makes all three arguments). According to the first argument, a constitution should be seen as expressing the principles essential to a democratic society, which courts debate in relation to a given case in a deliberative manner. As such their judgments can be seen as the product of an ideal democratic procedure that expresses the public reasoning of a democratic community. The second argument sees litigation as providing citizens with an additional and more 
direct avenue for advancing their interests and contesting their neglect or suppression by governments. The third argument conceives judges as representatives who can be expected to act on behalf of citizens because of the quality of the process of authorisation and the values they may be presumed to hold. Though analytically distinct, they prove mutually supportive and necessary to each other-with the first the lynch-pin of the other two (Dworkin 1996: 6-7).

All three arguments treat these alleged democratic qualities as intrinsic properties of well designed constitutions and an associated legal and judicial process. They are held to operate independently of any electoral process-indeed, they are believed to result largely from that independence. On these accounts, therefore, courts may be counter-majoritarian but they are not anti-democratic (Dworkin 1996: 7, 17-19). Rather, they offer a superior form of democracy that can legitimately oversee and correct the supposed failings of electoral forms of democracy. This claim will be challenged below. Instead of viewing courts as defining and maintaining the democratic qualities of the political system, it proves more appropriate to reverse this perspective and note how courts possess important and necessary democratic qualities precisely because they are embedded within and framed by a democratic political system. That is not to deny that courts supplement democracy in valuable ways-not least in ensuring the impartial and equitable application of democratically determined legislation. However, the necessary democratic qualities they possess in doing so derive from the legal and judicial system being a part of a democratic society characterised by political equality. The reason for this being so is simple: namely, that the only way to ensure all citizens enjoy an equal status is to subject state institutions-including courts-to a process that provides them with an equal say. Given citizens disagree about the principles and interpretations of them that best realise democratic equality, these cannot be defined or applied entirely outside a democratic process without losing democratic legitimacy and failing to treat citizens with equal concern and respect as having an equal stake in the configuration of their political community (Bellamy 2012). Democratic processes and democratic outcomes are linked.

The three arguments discussed below have long figured in the normative literature. They are especially prominent among those North American legal and political philosophers who regard the Supreme Court as encapsulating the 'American ideal' of ensuring government 'under principle' by giving final authority to judges charged with a 'moral reading' of the constitution. Ronald Dworkin even describes this arrangement as 'the most important contribution our [i.e., the United States'] history has given to political theory' (Dworkin 1996: 6). All three arguments tend to be presented as largely logical and conceptual in nature. However, they rest on a number of implicit and occasionally explicit empirical assumptions about the merits of courts and the demerits of electoral democracy. Although some empirical work has explored how far these assumptions meet these theorists' normative expectations about the legal and political process (for a useful summary of this research, see Tushnet 1999: chaps. 6 and 7), other work tends to take their normative expectations as read and defends the democratic legitimacy of judicial supremacy and litigation campaigns on this basis (e.g., Irons 1988). The main thrust of the following analysis will be accordingly to challenge the conceptual and normative underpinning of these arguments, though where relevant I will also note their questionable empirical basis.

\section{Courts as Ideal Democracy}

The first argument holds that constitutional courts are not counter-democratic but upholders of the democratic ideals enshrined in the constitution whose deliberations can 
themselves be regarded as exemplary of a true democratic process. This thesis has been given a substantive (Dworkin 1996) and a procedural reading (Ely 1980; Habermas 1996): as ensuring that either the outcomes of democratic decisions or the processes by which they are made are consistent with democratic values. Advocates of the procedural, input, approach maintain it is less contentious then the substantive, outcome, approach. However, in practice each has a tendency to shade into the other. If theorists from the former camp propose those procedures they believe most conducive to producing certain substantive outcomes, those from the latter camp tend to draw substantive conclusions from procedural arguments, as when they argue that the functioning of a given process assumes certain substantive social and economic preconditions. Space prevents my surveying all the variations on this argument (for such a survey, see Bellamy 2007: chap. 3). Here I restrict my analysis to one prominent example, that of John Rawls (1993). Rawls attempts to cut through the substantive-procedural distinction by conceiving of the public reasons that justify both substance and process as matters of political right or justice that are distinct from—but compatible with—any reasonable conception of the good that a democratic politics might be employed to promote (Rawls 1993: 213). He seeks a consensus around a distinctively democratic mode of argumentation that can be employed by courts to justify their judgments. Whereas some such move offers a necessary underpinning for the view that courts possess democratic legitimacy in and of themselves, I shall argue that it cannot secure the consensual support it requires if it is to provide a source of democratic legitimacy independent of any democratic process.

Rawls claims that the Supreme Court 'is the exemplar of public reason' (Rawls 1993: 216, 231), and that its standing in this regard is triply democratic. First, it upholds the principles that are intrinsic to the democratic public sphere. It may override certain decisions of that democratic process but only to preserve democracy. Second, the Court deliberates in an ideally democratic way because it is constrained when it comes to deciding issues that raise 'constitutional essentials' to only employ public reasons-reasons that simply reflect the values of a democratic society and process - when reaching its judgment. Third, the Court has a democratic mandate from the people, as the authorisers of the constitution and the ultimate arbiters of how it should be interpreted. These democratic credentials are mutually sustaining, yet ultimately fail. Given, as we shall see, the first proves suspect and gains little or no support from the third, the basis for the second collapses.

Rawls' theory rests on a view of the constitution as the repository of those public reasons that democratic citizens can reach 'practical agreement' about in relation to two sets of 'constitutional essentials'. These two sets concern, respectively, 'the general structure of government and the political process', on the one hand, and the 'equal basic rights and liberties of citizenship that legislative majorities are to respect', on the other (Rawls 1993: 227). As such, his account encompasses both the procedural and the substantive reading given that the second set is not limited to those rights and liberties that are inherent to the democratic process. Nevertheless, his scheme is limited to 'political justice', its aim being to fix 'once and for all' the procedures through which citizens 'can express ... their reasoned democratic will' and the protections necessary for 'guaranteeing the security and independence of citizens' (Rawls 1993: 232).

Rawls sees disagreement about the nature of the good life as 'reasonable' and inevitable in a liberal society, committed to tolerating a plurality of values and ideas and promoting experiments in living. Yet, he considers it a matter of 'the greatest urgency' that citizens agree on the basic rules of the political game which determine how these disagreements are to be conducted and limit the extent to which they can be concluded by closing off the 
possibility of dissent or the capacity to adopt alternative ways of living (Rawls 1993: 227). Consequently, he believes the public reasons that derive from political justice must be as far as possible separate from any given conception of the political (or any other) good citizens may hold. They are intended to be reasons that all citizens can acknowledge as guiding the pursuit and promotion of their different and often conflicting and incompatible conceptions of the good within the public sphere, so as to show the views and activities of others equal concern and respect. These reasons do not follow from or seek to determine what good citizens should pursue. They merely constrain how they can use politics or the law to protect or support whatever good they may value and to regulate their interactions with others (Rawls 1993: 216-20).

Public reasons contrast with the 'private' reasons of the various non-public associations and bodies found in civil society or of autocratic or aristocratic regimes that serve the particular interests of a given group of people rather than the public as a whole (Rawls 1993: 220-2). ${ }^{1} \mathrm{~A}$ private association such as a Church need only be open to those who share its system of beliefs. It can even be hierarchically ordered, with believers accepting the authority of priests in matters of religious doctrine by virtue of their learning and devoutness. Likewise, firms can require employees for the purposes of their work to share its goals and follow the directions of the management as to how best to achieve them. Nevertheless, these private associations, like the political authorities that may regulate them, must operate in ways that are consistent with a public framework which allows their peaceful coexistence with other associations and that does not impinge on their members' status as citizens. Once they enter the public sphere, they have a moral duty of civility to couch their views in ways consistent with public reasons.

Rawls claims such public reasoning is 'characteristic of a democratic people' (Rawls 1993: 213) but is ambiguous as to whether it is a necessary feature of all democratic politics. Although he starts by asserting that 'many if not most political questions do not concern those fundamental matters' that invoke public reason (Rawls 1993: 214), he later backtracks to suggest that all public policies may touch on them but in ways that are not always entirely clear (Rawls 1993: 215). Whereas he thinks agreement on what public reason dictates for how power is acquired and limited is both more urgent and easier to reach because what is required is relatively straightforward to specify, he believes social and economic arrangements allow for 'wide differences of reasonable opinion' given 'they rest on complicated inferences and intuitive judgments that require us to assess complex social and economic information about topics poorly understood' (Rawls 1993: 228-9). However, given all collective decisions involve state coercion to some degree, not just politicians but also citizens should seek to justify their view of them in terms of public reason, regardless of their personal grounds for voting a certain way on a given matter. Indeed, though Rawls' account appears initially parsimonious in its foundations and limited in application, he concludes by considering that public reason will ultimately involve convergence on the 'most reasonable' view of justice, a position for which he proposes his own theory (Rawls 1993: 227). Despite its modest beginnings, therefore, Rawls' argument concludes remarkably immodestly given the huge critical literature devoted to his famous work. This hubristic move proves both unavoidable and fatal to his thesis.

Rawls regards the democratic integrity of a constitutional court's position as depending on a consensus on political justice that can be applied in a reasonably clear-cut manner, at least so far as securing the equal rights and liberties of citizens in the operation of political procedures is concerned. As we saw, Rawls regards disagreement among 'comprehensive 
religious, philosophical, and moral doctrines' as inevitable and reasonable, and so dissents from Dworkin's view that the court can appeal to 'a conception of morality as such' or even 'political morality' (Rawls 1993: 236 n. 25). Nevertheless, he sees agreement on political justice as vital if we are to have a stable basis on which to conduct these disagreements about religion, morality and so on (Rawls 1993: 228). Yet, it is unclear that disagreement about political justice-including Rawls' own theory of justice-is any less reasonable than disagreement about the good.

Rawls attributes moral disagreement to what he terms 'the burdens of judgment' (Rawls 1993: 54-8). These burdens refer to the normative and empirical difficulties that attend our practical reasoning. The normative difficulties arise from the problems of assessing which factors are morally relevant to a given issue or how moral factors of different kinds might be combined or prioritised, the overcoming of the vagueness of our concepts, especially when it comes to hard cases, and of reconciling the divergent moral views that people's different life experiences may lead them to adopt. The empirical difficulties reflect the problems within complex and open societies of weighing up evidence, identifying causal processes and estimating the consequences of different decisions and policies. Yet precisely such normative and empirical difficulties characterise disagreements about issues of political justice such as the limits to freedom of speech, the propriety of particular anti-terrorist measures, the scope of privacy and so on. Here too concepts are vague, different life experiences lead to divergent assessments of what is morally important, the bearing of evidence is hard to assess and causal processes difficult to read.

Proponents of different conceptions of the good can certainly hold similar views of the right, so that there can be Catholic, Protestant and Humanist Rawlsean liberals, say. However, those who embrace the same conceptions of the good may also differ about the right, so that there can be Catholic, Protestant and Humanist Burkean conservatives as well. As Rawls concedes, these differences may reflect to some degree their different understandings of their various conceptions of the good. Yet, even if they manage to put these conceptions to one side-which, as we shall see in the next section, may be doubted-their differences over the right will be characterised by the self-same burdensome judgments that characterise their disagreements about the good. Conservatives and liberals will each understand rights and justice in different ways, with their ideological disagreements being mired in identical normative and empirical difficulties to those Rawls associates with their differing comprehensive philosophical conceptions.

The need for democratic politics flows as much from disagreements about the right as about the good (Waldron 1999: 105-6). Debates between (and within) Labour and Conservatives in the UK or Democrats and Republicans in the United States are not disagreements about how to apply agreed principles of democratic justice but about which among a number of rival principles to apply, be they libertarian, social democratic or a mix of both. Yet despite these disagreements, some collective policies will need to be decided upon. The burdens of judgment and the resulting partiality and potential fallibility of all human reasoning about the right as well as the good, mean that no individual or group of individuals can claim to be a better judge of another individual's interests than him or her self. Consequently, fairness dictates that collective decisions should be made in such a way that those persons whose common world is shaped by them can advance their interests on an equal basis to everyone else. In this regard, democracy embodies the 'right to have rights' of citizens-it offers the mechanism through which their different views on justice and the good are treated with 
equal respect and their interests and ideals may be shown equal concern (Bellamy 2012; Waldron 1999: chap. 11).

It might be argued that this process requires at the very least that we agree on the rights intrinsic to democratic procedures (Ely 1980; Habermas 1996). As we saw, though Rawls contends there is more to political justice than purely procedural matters, he believes these are easier and the most important to reach agreement on (Rawls 1993: 215, 229-30). However, turning to process rather than substance provides no solution to the above difficulties. Not only are citizens' substantive positions often implicated in their views of process, so that they judge a process by how far it is likely to achieve substantive results they approve of, but also there can be purely procedural disagreements over issues such as whether deliberation promotes groupthink or better informed decision-making, the relative merits of different electoral systems, the value of second chambers and so on. Procedural judgments prove as burdensome as substantive ones. Even basic procedural issues, such as the right to vote, can be controversial. For example, Rawls' dissent from the Supreme Court's judgment in Buckley, that decided the limits on expenditures imposed by the Election Act Amendment of 1974 were unconstitutional, turns not on the Court failing to consider democratic values but on his view that its reasoning was faulty with regard to the normative and empirical assumptions it made when interpreting those values (Rawls 1993: 359-60).

Rawls believes disagreement cannot go all the way down to the very constitution of the democratic process without placing the upholders of democracy in a dilemma. For if there is disagreement about the nature of democracy, a democratic process that many participants within it feel is not truly democratic cannot be a legitimate means to decide questions about the nature of democracy itself. To the degree that this is so, however, having a court decide these issues offers no solution to the dilemma (Waldron 1999: 298-9). In the absence of an agreed conception of political justice, there is no reason to suppose the composition, competences and decisions of any court will be any less contentious than those of elected representatives in the legislature. Nor, as is sometimes suggested, can it be supposed the decisions of a court on the democratic process will be less self-interested or more independent than those of an elected legislature (Waldron 1999: 296-8). For its members have the same interest in the democratic process as all other citizens, while many of their decisions will implicitly and sometimes explicitly touch on its own role in the legal and political system. However imperfectly, a less than ideal democratic process will at least offer a roughly equal measure of popular participation in deciding these disagreements.

A one-off constitutional referendum also offers no help in legitimising the democratic standing of the court. Following Bruce Ackerman (1991), Rawls distinguishes 'normal' from 'constitutional' politics and argues that a constitutional democracy is 'dualist'. Normal legislation is democratically legitimised by an electoral process involving majority rule, but is subject to the higher law of the constitution which acquires democratic legitimacy in a more demanding, super-majoritarian, way through garnering the overwhelming support of the people as a whole at an exceptional constitutional moment, when the very character of the political regime as a whole comes into question (Rawls 1993: 232-5). Though imperfect and potentially fallible, Rawls considers such real instances of popular constitutionalism as the best available approximation to the ideal democratic contract that grounds his theory. They show the principles of political justice that order a given democratic society are 'plain truths now widely accepted' (Rawls 1993: 225).

This argument confuses popular sovereignty with democracy (Waldron 1999: 258-9). 'We the people' may be sovereign but that does not make whatever institutions or mechanisms they 
choose ipso facto democratic, for they may deploy that sovereign power to establish a nondemocratic political system. Yet democratic legitimacy requires the system be democratic in its operation and not merely in its establishment. One reason is that constitutional documents continue to be controversial and in need of interpretation so long as reasonable disagreement about justice persists. If reasonable disagreement about political justice proves ongoing, and so present within almost all debates on public policy in elections and the legislature, then no valid reason exists for assuming that the popular determination at time $t$ should prevail over that at $t$ +1 , when changes in society and in the people and their views that compose it suggest a new determination of fundamental questions. To make such changes subject either to the evolving views of the judiciary or a super-majority of citizens as a whole in a special referendum denies the very essence of democracy - the equal right of citizens to participate in the framing of their common life. It effectively weights the views of a few judges or of past citizens over those of present citizens. As such it fails the criteria of equal concern and respect.

Rawls accepts that a legislature itself may be the 'exemplar of public reason' in certain democratic societies (Rawls 1993: 234-5, especially n. 21). What has been argued above is that it has a superior basis for that role than constitutional courts through being the forum for the ongoing reasoning of the public - a place where citizens may voice their reasonable disagreements about the basis of their collective co-existence, albeit through their duly elected representatives. If these disagreements extend to the very rules of the game then there will be no set of undisputed democratic values and certainly no authoritative way of interpreting them that might justify the exemplary role Rawls accords to the Supreme Court. That need not mean that a role could not exist for courts to be a forum for individuals or groups to contest the fairness and equity of legislation in relation to particular cases. However, it does suggest that, as with the UK Human Rights Act, for example, the final word should rest with the legislature (Bellamy 2011). As we shall see, it is only then that courts can offer an alternative and democratically legitimate forum for popular participation in public reasoning-either directly or through the judiciary as their representatives. Otherwise, they will be forced to rely on flawed arguments similar to those of Rawls criticised above.

\section{Courts as Participatory Democracy}

Few would deny that the electoral process often fails to engage citizens or to adequately reflect or respond to the important concerns of a significant number of them. Indeed, most democracies have experienced falling voter turnout in recent years. By contrast, participation in a range of other kinds of political activism remains comparatively buoyant. Many see support for litigation by public interest groups, such as consumer, environmental or anti-discrimination campaigners, as among the most important of these alternative forms of civic engagement (Kavanagh 2003 and see the contributions by Cichowski, Keleman and Vanhala to this special issue). Yet, how democratic is it?

Following Philip Pettit (2000), we can distinguish two forms of democracy-'authorial' and 'editorial' or 'contestatory', although, as will be explored below, the latter two are not entirely identical. Authorial democracy involves citizens authoring collective policies. Within electoral systems this arises from their indirect influence over legislation and the policies of elected government officials. As we have seen, the claim to democratic legitimacy stems from the electoral process being a public mechanism that allows citizens to advance their interests on an equal basis to each other. Even taking into account declining electoral turnout, national elections in most democracies typically engage the participation of over 
$50 \%$ of the electorate, often amounting to several million voters (Hay 2007: 13-14). No litigation campaign achieves anything like the same degree of support or involvement. Likewise, campaigning organisations typically have even lower levels of membership than political parties. Even when they do enjoy a significant following, they lack anything equivalent to the electoral incentive that leads parties to weigh the views and interests of all citizens on a sufficiently equitable basis to secure a majority, usually by appealing to the median voterbe it alone or as part of a winning coalition (Ordeshook 1986: 245-57).

Of course, it could be argued that within the context of a given case a court will hear from all affected parties. In this way, the legal forum comes to reflect the wider political forum. However, the incentives for rival groups mounting or blocking legal challenges are not symmetrical to the electoral incentives of parties. In the legal case, it will be the specific impact of a particular policy that will be at issue. To litigate there must also be a case in law, while only certain parties have standing. As a result, a whole range of views and interests of potentially affected persons may be excluded. Meanwhile, those with deep pockets can have an even more disproportionate influence in the legal than in the political sphere. However wealthy they may be, rich party funders must ultimately win the votes of those poorer than themselves. They cannot straightforwardly buy an advocate to argue their case on an equal basis to a much more poorly resourced advocate supported by very many more people. Imperfect and inequitable though electoral processes frequently are, legal processes risk being even more so.

Above all, the final determination of a case lies not with the litigators but the judiciary. It is their vote alone that counts in court-indeed, nobody else has a right to vote. Even if the campaigns and hearings themselves were as free and equal as the electoral process, a crucial element is missing - it is not the parties to this process who determine the outcome. Litigation offers the right to petition for rights but is not itself a right to define and determine the rights of the collectivity. Thus, the credentials of litigation as a mode of 'authorial' democracy are weak.

Certain of the imperfections and inequities of the legal process could be said to be balanced by the constraints of the law itself. Not all arguments will be valid. That may exclude certain injustices getting a legal hearing but it will also rule out certain unjust views being presented and allow many that have been legislated for to be challenged-not least by groups whose views may not have gained an adequate consideration within the electoral process. Moreover, the judges can only decide a case on the basis of legislation or a constitution that has itself been democratically endorsed. These constraints move litigation towards the model of 'editorial' democracy. However, the strongest case for the democratic legitimacy of this practice depends on something like Rawls' argument about public reason that we criticised in the last section. In other words, it assumes that the editorial rules provided by the constitution reflect a democratic consensus as to the norms of a democratic society and that they can be applied in an impartial way that reflects this consensus by the court. If neither is true, then the danger exists that the court may edit out what needs editing in or vice versa, inventing or interpreting supposedly democratic norms in a largely arbitrary way. For example, think of the Lochner period when the state and federal courts in the United States struck down some 150 pieces of labour legislation, including measures to outlaw child labour, on the grounds that they violated freedom of contract (Waldron 1999: 288). Or consider the Canadian Court's declaration that restrictions on tobacco advertising undermined freedom of speech (Hirschl 2004: 120).

Editorial democracy presumes to offer public criteria that can distinguish groups that are heard within the democratic process but fail to convince from those who either fail to get a hearing at all or whose very right to be treated as worthy of a hearing is being denied. As a result, those who litigate in this spirit argue that either the process was deficient or that the 
decision itself denies them their democratic rights. Yet, we saw how these matters prove impossible to determine without the judiciary taking a position on the very disagreements about political justice that may have been at issue in the legislative process. Thus, an intense minority, who feel very strongly in favour of a policy that the rest of the population feel moderately opposed to, may argue the electoral process has let them down by not appropriately weighting the intensity of their views. However, even if this case is treated as a 'mere' procedural issue it raises contentious and burdensome judgments over process rights. For example, who deserves more of a say: residents of an area where an airport is to be built or the general population? That could be treated as a matter of the appropriate competences or balance between local and national decisionmaking, but unless there was a very clear and settled view in law on the issue it is doubtful the judiciary could invoke a consensus on this topic. They may be simply reconsidering a question that legislators had themselves thought long and hard about when deciding to build the airport where they did. It is also more than likely that most views of the procedural question will involve a stance on what an acceptable outcome would be and hence of the relative importance of the interests involved. Once again, though, these points may have been raised and deliberated on already, with the legislature's decision itself seeking to balance the impact on residents, environmental concerns and the needs of the economy on as equitable and fair a basis as possible.

As a result, in deciding the question on either procedural or substantive grounds the court will be deliberating like a legislature, even if it deploys the rhetoric of constitutionalism when doing so. It need not be that the legislature or administration ignored democratic rights, they just offered a different interpretation of them to that favoured by the litigators or-if convinced by the litigants' reasoning - the court. But why then should this second view prevail? The danger arises that litigation simply offers a venue for those who lose fair and square in politics to gain a second hearing by concentrating all their resources on winning on a particular issue in law. It may distort rather than support the democratic process by diverting political resources to fighting a battle that the majority feels has already been legitimately settled in a way that offers a more rounded and comprehensive appreciation of all the rights and views of rights at issue (Tushnet 1999: 138-40).

What about examples that most people would regard as legitimate? Rawls sees the civil rights movement in the United States as a prime instance of editorial democracy (Rawls 1993: 249-51). He argues the democratic legitimacy of the campaign rested on its leaders being able to appeal to the public reason of the constitution as exemplified in the core court decision of Brown v. Board of Education. Nevertheless, he acknowledges that the rhetoric of the campaign was typically couched in terms of a more comprehensive conception of the good, often religious in character, to reinforce their contention that in this area equal could not mean differential or separate treatment. Indeed, given the court had had a history of upholding racial inequality it was perhaps unsurprising that they should feel a need to justify a particular reading of the constitution in terms of a wider set of considerations. In other words, their aim was not to appeal to a consensus on democratic values but to contest and change the dominant understanding of those values. That may well be the case with most litigation campaigns. Contestatory litigation blends into authorial democracy at this point. Yet, we have remarked how the democratic credentials of this form of litigation are questionable due to the absence of an electoral process. In fact the key success of the movement came with the passing by Congress of the Civil Rights and Voting Rights Acts in 1964 and 1965, while it has been through the courts that crucial elements of this legislation is currently being successfully eroded (Rosenberg 1991).

None of the above denies that there can be excluded and unpopular groups who through prejudice or oversight fail to have their interests adequately considered within the 
electoral process. Measures that appear generally beneficial may also have unintended and unanticipated harmful consequences for particular individuals or in certain unforeseen circumstances. Courts may provide a valuable fire alarm in such cases by allowing groups or individuals to raise such concerns. However, given there is no uncontentious way a court could decide these questions on the basis of democratic reasons alone, the only true democratic forum for the final decision must surely be one that is itself subject to an inclusive democratic processnamely, the legislature (Bellamy 2007: chap. 6).

\section{Courts as Representative Democracy}

The final argument consists of a negative and a positive thesis under the heading of representation - the one to dispute the aforementioned democratic qualities of the legislature, the other to buttress those of the courts (Kyritsis 2006). According to the negative thesis, the democratic critique of courts fails because in representative democracies legislation cannot be regarded as reflecting the popular will. Rather, it results from the deliberations of representatives in the legislature. However, representatives are neither delegates nor proxies of their constituents. Instead, they are more like trustees (Kyritsis 2006: 743-4). As such, a democratic case against judicial review based on the equal right of citizens to participate in legislation proves as telling against the legislature as it does against constitutional courts. For legislators likewise possess a superior voting weight to ordinary citizens and exercise their independent moral judgment when making decisions concerning the whole of the political community, often going against the express wishes of the citizens who voted for them. The positive thesis notes that judges may likewise be considered as trustees, acting in this sense as representatives in an analogous way to most members of the legislature. However, once again their chief democratic quality rests on their engaging in conscientious and impartial deliberation on the public good (Kyritsis 2006: 748-50).

The chief weight of this argument rests on the negative thesis. Yet, the delegate-trustee distinction on which it relies proves too sharply drawn and fails to take into account the full range of representative roles politicians play. Not only do delegation and trusteeship form the end points of a continuum rather than opposed and incompatible concepts (Pitkin 1967: 121), but also these and other roles can be combined. The key is how the processes of authorisation and accountability influence the behaviour of representatives by respectively screening for certain qualities and sanctioning their subsequent failure to meet expectations. For example, Jane Mansbridge (2003) has distinguished promissory, anticipatory and gyroscopic representation. The first category corresponds most to the delegatory model, with representatives assessed by their fidelity to their electoral promises. Most representatives belong to parties and are subject to party discipline, and the findings of the manifesto research group suggest that once elected parties do keep faith to their electoral promises to a remarkable degree (Klingermann et al. 1994). Of course, manifesto promises are often vague policy goals, so representatives may still act as trustees and deliberate over the appropriate means to meet these promised ends. Yet, they are also sensitive to changing attitudes among the electorate in response to new circumstances or the success or failure of different policies. As such, representatives also operate as per the second category and anticipate what they think voters will approve at the next election. Finally, representatives will always have to face unanticipated decisions. However, in doing so voters may be able to expect they will decide in expected ways without external incentives because they have been selected on the basis of their prior beliefs and convictions. Here, representatives fit into the third category 
and act as gyroscopes, rotating around a set of relatively stable convictions. Even so, although their authority derives for the most part from the process of authorisation, they are liable to be held accountable should they act other than expected.

In all these cases, representatives are sensitive to voter preferences and in dialogue with them in a way that the judiciary largely are not. To the degree that this is the case, it is because judges operate in a democratic environment. Thus, they can sometimes be categorised under gyroscopic and anticipatory representation. The gyroscopic model operates where the selection of judges is subject to direct political control, as in the United States, with ideological attitudes as well as professional merit being among the qualities that decide the selection of Supreme Court Justices. By and large, the attitudes expressed in Senate hearings correlate remarkably well with their subsequent decisions (Segal and Spaeth 1993). Yet, even where there is greater independence from direct political interference, courts will wish their decisions to gain acceptance by governments and citizens alike. Otherwise, they risk both a loss of legitimacy and an implementation deficit, given there are many ways a judgment can be blocked or undermined through half-hearted, underfunded or delayed compliance. As a result, they practise a weak form of anticipatory representation, so that 'Courts follow the polls' to the extent of reflecting sustained, national popular opinion (Dahl 1957).

Legislators are only trustees to a limited degree. To the extent judges are, then the degree they can be trusted to uphold democratic values does not rest on the norms embedded in the constitution or its periodic endorsement by referenda-arguments akin to those of Rawls criticised earlier. Rather, their representativeness stems from a variety of indirect democratic pressures. Once again, the democratic legitimacy of the court arises from its being within an electoral political system rather than independent from it.

\section{Conclusion}

Constitutional courts have increasingly sought to justify their role on democratic grounds. They claim to uphold democratic values, provide a venue for democratic participation and contestation and to act as representatives of the people. These three functions prove interdependent even if analytically distinct. A court only allows for democratic participation and represents the people's democratic interests in so far as it accurately upholds commonly avowable democratic values. In their turn, these democratic values can only be regarded as reflecting public reason to the extent they find support in the actual reasons of the public and judges accurately represent their views.

However, none of these conditions is likely to be met outwith an actual democratic process. The view of constitutional democrats that courts and constitutions offer an ideal democratic framework for the real democratic process proves the opposite of the reality. The legitimacy of democratic processes derives from their own inherent constitutional properties as mechanisms for citizens to engage with each on other on equal terms. To the extent courts possess similar qualities they do so because of the indirect influence of that process. Political equality promotes equality before and in the law, not vice versa (Holmes 2003). It is because-or to the extent that-citizens have acquired a roughly equal share of political power that legal institutions likewise place them on an equal footing. In part that is because the political, civil and social norms embodied in law can only be taken advantage of in so far as the citizens to whom they apply are sufficiently organised to be able to exploit them. In other words, courts may offer a forum for participation and contestatory democracy but their ability to do so depends on the democratic opportunity structure within the social and 
political systems as a whole. In part, that is because democratic justice cannot be separated from the good of the democratic society as defined by its citizens. As a result, judges cannot be viewed simply as trustees of a fixed democratic good, but do need to be responsive to and represent widespread and sustained popular opinion.

These are not arguments for electing judges and holding regular referenda on the constitution in order to democratise them directly. To do so would unnecessarily and confusingly duplicate the task of the legislature and neglect that of the judiciary to provide the consistent and impartial application of duly enacted law to particular cases. However, it remains important that courts undertake their proper tasks in an appropriately democratic spirit-not least by treating all citizens equitably and acting as representatives of the public interest. The argument has been that they cannot do so because of any inherently democratic qualities of the constitution or the judicial process. Democratic norms can only be legitimately and justifiably defined and applied through a democratic process. Judges need to act independently to be impartial, but if the judicial system as a whole is to be suitably democratic then it will need to be responsive to the democratic reasoning of the public and their representatives, not least through their capacity to organise themselves democratically through the electoral system and other social structures. Courts supplement this democratic process in a number of ways_-including signalling how a given case may reveal that legislation has overlooked or unduly minimised certain adverse consequences for certain individuals in given circumstances. Yet they do so through being embedded in and dependent upon a democratic system in which the exemplars of constitutional reasoning are the people themselves and their democratic representatives. As Learned Hand noted 60 years ago (Hand 1953: 155-65), absent that condition, no court can save democracy, where it prevails no court need save it, while the attempt to entrust the responsibility for exemplary constitutional reasoning to the courts can only erode its presence among voters and politicians alike.

\section{ACKNOWLEDGEMENTS}

I am grateful to Cristina Parau and Oliver Gerstenberg for their very helpful comments on an early draft of this article.

\section{NOTE}

1. As Rawls notes, there is no purely personal 'private' reason, so even these reasons are 'social'. However, they are not 'public' in his sense of addressing other members of society in their guise as fellow citizens, as opposed to say fellow believers.

\section{REFERENCES}

ACKERMAN, B. 1991. We the People: Foundations. Cambridge, MA: Harvard University Press.

Bellamy, R. 2007. Political Constitutionalism: A Republican Defence of the Constitutionality of Democracy. Cambridge: Cambridge University Press

BeLLAmy, R. 2011. Political constitutionalism and the Human Rights Act. International Journal of Constitutional Law (I-Con) 9: 86-111.

BeLLAMY, R. 2012. Rights as democracy. Critical Review of International Social and Political Philosophy 15 (4): 449-71.

BICKEL, A. 1986, The Least Dangerous Branch: The Supreme Court at the Bar of Politics (2nd ed.). New Haven: Yale University Press. 
ChRISTIANO, T. 2008. The Constitution of Equality: Democratic Authority and its Limits. Oxford: Oxford University Press.

DAHL, R. A. 1957. Decision-making in a democracy: the Supreme Court as national policymaker. Journal of Public Law 6: 279-95.

DWORKIN, R. 1996. Freedom's Law: The Moral Reading of the American Constitution. Oxford: Oxford University Press

ELY, J. H. 1980. Democracy and Distrust: A Theory of Judicial Review. Cambridge, MA: Harvard University Press.

habermas, J. 1996. Between Facts and Norms, trans. W. Rehg. Cambridge: Polity Press.

HAND, L. 1953. The contribution of an independent judiciary to civilization. In The Spirit of Liberty, edited by I. Dillard. New York: Knopf.

HAND, L. 1958. The Bill of Rights. Cambridge, MA: Harvard University Press.

HAY, C. 2007. Why We Hate Politics. Cambridge: Polity Press.

HIRSCHL, R. 2004 .Towards Juristocracy. Cambridge, MA: Harvard University Press.

HOLMES, S. 2003. Lineages of the rule of law. In Democracy and the Rule of Law, edited by J. M. Maravall and A. Przeworski. Cambridge: Cambridge University Press, chap. 1.

IRONS, PETER H. 1988. The Courage of their Convictions. New York: Free Press.

KAVANAGH, A. 2003. Participation and judicial review: a reply to Jeremy Waldron. Law and Philosophy 22: $451-86$.

KLINGermanN, H.-D., R. I. Hofferbert and I. Budge. 1994. Parties, Policies and Democracy. Oxford: Westview Press.

KYRITSIS, D. 2006. Representation and Waldron's objection to judicial review. Oxford Journal of Legal Studies 26 (4): $733-51$.

MANSBRIDGE, J. 2003. Rethinking representation. American Political Science Review 97 (4): 515-28.

ORDESHOOK, P. C. 1986. Game Theory and Political Theory. Cambridge: Cambridge University Press.

PETTIT, P. 2000. Democracy: electoral and contestatory. In Designing Democratic Institutions, edited by

I. Shapiro and S. Macedo. New York: New York University Press, pp. 105-44.

PITKIN, H. F. 1967. The Concept of Representation. Berkeley: University of California Press.

RAWLS, J. 1993. Political Liberalism. New York: Columbia University Press.

rosenberg, G. 1991. The Hollow Hope: Can Courts Bring About Social Change? Chicago: Chicago University Press.

SEGAL, J. A. and H. J. SPAETH. 1993. The Supreme Court and the Attitudinal Model. Cambridge: Cambridge University Press.

TUSHnet, M. 1999. Taking the Constitution Away from the Courts. Princeton: Princeton University Press. WALDRON, J. 1999. Law and Disagreement. Oxford: Oxford University Press.

Richard Bellamy is the incoming Director of the Max Weber Programme at the European University Institute, where he is also a professor in the Department of Social and Political Science, on extended leave from his position as Professor of Political Science at University College London. His many publications include Liberalism and Pluralism: Towards a Politics of Compromise (Routledge, 1999) and Political Constitutionalism: A Republican Defence of the Constitutionality of Democracy (Cambridge University Press, 2007). He currently holds a Leverhulme Research Fellowship and is a Fellow at the Hanse-Wissenschaftkolleg (HWK), where he is completing a book on A Republic of European States for Cambridge University Press. Email: r.bellamy@ucl.ac.uk 